\title{
Functional and Physicochemical Properties of Watermelon (Citrullus Lanatus) Seed and Seed-Oil
}

\author{
Oyeleke, G.O. ${ }^{1}$, Olagunju, E.O. ${ }^{2}$, Ojo, A. ${ }^{3}$ \\ ${ }^{1,2}$ Science Laboratory Technology Department, Osun State Polytechnic, Iree, Nigeria. \\ ${ }^{3}$ Food Science and Technology Department, Osun State Polytechnic, Iree, Nigeria.
}

\begin{abstract}
The functional properties as well the physicochemical properties of watermelon seed and seed-oil were analyzed. The functional properties of the seed revealed that oil and water absorption capacities for the seed were $123.5 \pm 0.5 \%$ and $116.3 \pm 0.1 \%$. The foaming capacity and stability (after $2 \mathrm{hr}$ ) in \% were found to be $23.5 \pm 0.1 \%$ and $62.5 \pm 0.2 \%$ respectively while emulsion stability gave $0.325 \pm 0.001 \%$. Physicochemical properties of the oil extract from the seed using soxhlet extractor revealed the followings; iodine and acid values in $\mathrm{mgKOH} / \mathrm{g}$ and saponification value in $\mathrm{mgKOH} / 100 \mathrm{~g}$ were $148.5 \pm 0.5,74.5 \pm 0.5$ and $3.4 \pm 0.1$ respectively. Peroxide value of the oil was found to be $2.8 \pm 0.1$ meq $/ \mathrm{kg}$ while specific gravity determination gave 0.91. The low acid, iodine and peroxide values of the oil coupled with favourable functional properties makes the seed and the oil suitable for human consumption and therefore the result of this research work would provide further information on the domestic and industrial usage of the seed and seed-oil.
\end{abstract}

Keyword: Watermelon, seed, functional, physicochemical, industrial.

\section{Introduction}

Watermelon (Citrullus lanatus) is of the cucurbitaceae family. As a member of the cucurbitaceae, watermelon is related to the cantaloupe, squash and pumpkin and other plants that grows on vines on the ground. Watermelon is a good source of carotenoid and lycopene. Lycopene has been found to be protective against a growing list of cancer [1].

Watermelon is also expectedly high in citrulline; an amino acid the body make use of to make another amino acid, arginine (used in the urea cycle to remove ammoniacal from the body) [2]. Watermelon is delectable, thirst-quencher which helps quench the inflammable that contributes to conditions like asthma, atherosclerosis, diabetes, colon cancer and arthritis [3]. Cucurbit seeds are source of food particularly protein and oil [4]. Dehulled cucurbit seeds were reported to contain about 50\% fat and 35\% protein [5].

Watermelon fruit contained many smooth compressed seeds that thickened at the margin and of black or yellow-white colour [6]. Achu, et al., [7] reported high lipid level in five cucurbitaceae oil- seeds from different regions in Cameroon. Oil provides concentrated energy in diet and enhanced palatability. It worthy to note that major edible oils are from palm oil and peanut which are capital and labour intensive [8] and therefore there is need to source for good, cheap and novel source of oils that would be useful domestically and perhaps industrially.

The aim of this research work is to determine some functional properties of the seed and physicochemical properties of the oil extract with a view of harnessing it for consumption and possible industrial usage.

\section{Materials And Methods}

2.1 Collection and Sample Pretreatment

Matured watermelon fruits (fresh condition) were purchased from Thursday market, Ikirun, Osun State, Nigeria. The fruits were sliced open using a clean stainless steel laboratory knife. The seeds were washed severally with distilled water, sun-dried for a week, sorted to remove bad ones, shelled, grinded with a laboratory blender, packed in an air tight container and stored in a dessicator (containing silica gel) ready for further analysis.

\subsection{Methods}

The proximate composition was determined using AOAC, [9] methods and carbohydrate was done by difference method. The oil content of the powdered seed was done using soxhlet type of direct solvent extraction of the sample with petroleum ether (b.pt. $60-80^{\circ} \mathrm{C}$ ). At the end of the extraction, the solvent was evaporated and the flask dried in the oven at $60^{\circ} \mathrm{C}$ [10]. The physicochemical properties of the oil extract for specific gravity, iodine, peroxide, saponification and acid values were determined as described by AOAC, [9] methods. The functional properties for foaming capacity and stability, oil and water absorption capacities and 

emulsion stability (after $12 \mathrm{hr}$ ) of the seed were determined according to the methods described by Arawande and Borokini, [11].

\section{Results and Discussion}

\subsection{Results}

Table 1 Proximate composition (\%) of watermelon seed.

\begin{tabular}{lc}
\hline Parameter & Mean \pm S.D \\
\hline Moisture & $6.9 \pm 0.1$ \\
Protein & $27.4 \pm 0.5$ \\
Fat & $47.9 \pm 0.2$ \\
Ash & $4.1 \pm 0.1$ \\
Crude fibre & $3.8 \pm 0.1$ \\
Carbohydrate & $9.9 \pm 0.2$ \\
\hline
\end{tabular}

Results are average of duplicate determinations $=$ S.D

Table 2 Functional properties watermelon seed ( $\%$ ).

\begin{tabular}{lc}
\hline Parameter & Mean \pm S.D \\
\hline Foaming capacity & $23.5 \pm 0.1$ \\
Foaming stability (after $2 \mathrm{hr}$ ) & $62.5 \pm 0.2$ \\
Water absorption capacity & $116.3 \pm 0.1$ \\
Oil absorption capacity & $123.5 \pm 0.5$ \\
Emulsion stability (after $12 \mathrm{hrs}$ ) & $0.325 \pm 0.001$ \\
\hline
\end{tabular}

Results are of duplicate determinations \pm SD

Table 3 Physicochemical properties of watermelon seed oil.

\begin{tabular}{lc}
\hline Parameter & Mean \pm S.D \\
\hline Specific gravity & $0.91 \pm 0.01$ \\
Acid value $(\mathrm{mgKOH} / \mathrm{g}$ & $3.4 \pm 0.1$ \\
Peroxide value $(\mathrm{mgKOH} / \mathrm{g})$ & $2.8 \pm 0.1$ \\
Iodine value $(\mathrm{meq} / \mathrm{kg})$ & $74.5 \pm 0.5$ \\
Saponification value $(\mathrm{mgKOH} / 100 \mathrm{~g})$ & $148.5 \pm 0.5$ \\
\hline Results are average of duplicate determinations \pm S.D.
\end{tabular}

\subsection{Discussion}

From table 1, the moisture content of the seed was found to be $6.9 \pm 0.1 \%$. This value is higher compared to $5.7 \%$ reported for it by FAO [12] but similar to $6.46 \%$ and $6.56 \%$ reported for cottonseeds and sunflower seeds [13].

The protein content was $27.40 \pm 0.05 \%$, which was higher than $24.69 \pm 0.05$ and $20 \pm 0.12 \%$ obtained for unfermented groundnut and sesame seed by Ojokoh and Lawal,[14 ] and Nzikou et al.,[15] respectively. The value obtained for crude fat was $47.9 \pm 0.2 \%$ and therefore could be regarded as an oil seed. Our value is similar to $41.8-54.9 \%$ reported for some varieties of $C$. pepo by Murkovic et al., [16]. The lipid value of this seed is similar to those of sesame (53.5\%) and peanut (45.6\%) [13]. The ash content of the seed flour was found to be $4.1 \pm 0.01 \%$ which was a little bit lower comparable to $6.51 \pm 0.28 \%$ reported for jack bean by Arawande and Borokini, [11]. The crude fibre for the seed was found to be $3.8 \pm 0.1 \%$ which is lower compared to $11.88 \pm$ $0.02 \%$ reported for fluted pumpkin by Adebisi and Olagunju, [17]. The carbohydrate content obtained was $9.9 \%$ which was lower compared to $26 \%$ reported for sunflower [13].

Table 2 revealed the functional properties of the seed. The water absorption capacity (WAC) was found to be $116.3 \pm 0.1 \%$ which is lower compared to $200-288.8 \%$ for melon [18]. The WAC result showed that the seed is less hydrophobic and therefore would be a useful ingredient in viscous foods. The fat absorption capacity (FAC) was $123.5 \pm 0.5 \%$, this value was higher than $84.4 \%$ for soybean [19]. FAC is critical in determining the flavour retention in food materials. Emulsion stability (ES) was found to be $0.325 \pm 0.001 \%$ and is lower than $13.19 \pm 1.0 \%$ reported for Jack beans [11]. ES is important for stabilization of additives in production of foods like soup and cakes. The foaming capacity (FC) was $23.5 \pm 0.1 \%$ and is higher than $11.30 \%$ and $9 \%$ obtained for pear millet and quinoa flours by other researchers elsewhere. The high value of FC in watermelon seed flour suggests its use as a whipping or aerating agent in food system [11]. The foaming stability (FS) was determined to be $62.5 \pm 0.2 \%$ and is lower compared to $40 \%$ reported for wheat flour by Akubor and Badifu, [20].

Table 3 revealed the physicochemical properties of the watermelon seed oil (WSO). The specific gravity was found to be 0.91 which is lower than 0.964 reported for cashewnut seed oil [21]. The result showed that the oil is less dense than water and therefore would be useful in cream production as it will make the oil flow and spread easily on the skin. 
The saponification value was found to be $148.5 \pm 0.5 \mathrm{mg} / \mathrm{KOH} / 100 \mathrm{~g}$ in WSO, this value is higher than $115.94 \mathrm{mgKOH} / 100 \mathrm{~g}$ reported for both oven and sun dried watermelon seed oil [22]. The value obtained is less than $210.0 \pm 0.9 \mathrm{mgKOH} / 100 \mathrm{~g}$ reported for baobab seed oil [23], the low value obtained suggests that the oil might not be useful for soap production. The acid value was found to be $3.4 \pm 0.1 \mathrm{mgKOH} / \mathrm{g}$ in WSO; this value was not up to $11.73 \pm 1.40 \mathrm{mgKOH} / \mathrm{g}$ reported for $P$. thonningii by Jimoh and Oladiji, [24]. The acid value of $\leq$ $10 \mathrm{mgKOH} / \mathrm{g}$ confirmed the edibility of the oil as well as it stability to rancidity. The peroxide value was found to be $2.8 \pm 0.1 \mathrm{meq} / \mathrm{kg}$ of the oil. The value is low compared to $18.75 \%$ reported for sun-dried watermelon seed [22]. The low peroxide value is an indication that the oil does not contain much of trace elements (especially copper) and moisture which normally accelerates auto-oxidation [17]. The value is however within the permitted maximum peroxide value of not more than $10 \mathrm{meq}$ of peroxide per kilogram of oil.

The iodine value (I.V) of the oil was determined to be $74.5 \pm 0.5 \mathrm{mgKOH} / \mathrm{g}$. The value is very much higher than $38.50 \pm 0.67 \%$ and $23.25 \pm 0.02 \%$ reported by Oladimeji et al., [25] and Adebisi and Olagunju, [17] for Hausa melon seed and fluted pumpkin seed respectively. The low I.V of $<100$ however makes the oil unsuitable for paint making as it is a non drying oil.

\section{Conclusion}

The research work is an indication that great potential exists for the use of watermelon seed instead of throwing them away as waste after consuming the pulp. The seed could be used in infant food formulation and the seed- oil could also be a useful source of oil for both domestic and industrial uses instead of depending solely on palm oil and peanut oil that are scarce and costly.

\section{References}

[1] E. Cho, J.M. Seddon, B. Roser, E.C. Willet and S.E. Hankinson, Prospective study of intake of fruits, vegetables, vitamins and carotenoids and risk of age, Maculopathy, 6, 2004, 883-892.

[2] J.K. Collins, G. Wu, P. Perkins-veazie, K. Spears, P.L. Claypool, R.A. Baker, B.A. Clevidence, Watermelon consumption increases plasma arginine concentrations in adult, Nutr. Mar. 23(3), 2007, 261-266.

[3] L. Jian, A.H. Lee, C.W Binns, Tean and lycopene protect against prostate cancer. Asian pac. J. Nutr. 16 suppl. $453-457$.

[4] L.G. Hassan, N.A. Sanni, S.M. Dangoggo, M.J. Ladan, Nutritional value of bottle gourd (Lagenaria siceraria) seeds. Global J. Pure \& Applied Sci., Vol.4 No. 3, 2008, 301-306.

[5] F. Martins, Cucurbit seed as possible oil and protein sources for small scale household use in the hot humid tropics, oil/crop processing, 1998, 2.

[6] V.A. Sodeke, Extraction of oil from watermelon seed and analysis, Ouarterly research service, 2005, pp. 25-30.

[7] M.B. Achu, E. Fokou, C. Tchiegang, M. Fotso, F.M. Techonanguep, Nutritive value of some cucurbitaceae oilseeds from different regions in Cameroon. African J. Biotechnology, Vol. (4), 1329-1334.

[8] C. Agatemor, Studies of selected physicochemical properties of fluted pumpkin (Telfaira occidentalis Hook F.) seed oil and tropical almond (Terminalia catappia) seed oil, Pak. J. Nutr. 5(4), 306-307.

[9] A.O.A.C, Official methods of analysis, Association of official analytical chemists (18 ${ }^{\text {th }}$ edition Washington, DC, U.S.A, 2005).

[10] G.C. Ojieh, O.M. Oluba, Y.R. Ogunlowo, K.E. Adebisi, R.T. Orole, Compositional studies of Citrullus lanatus (Egusi melon) seed. The internet J. of Nutr. and Wellness, Vol. 6 No 1, 1-5.

[11] J.O. Arawande, F.B. Borokin, Comparative study on chemical composition and functional properties of three Nigerian legumes (Jack beans, pigeon pea and cowpea), J. Emerging Trends in Engineering and Applied Sciences (JETEAS) 1 (1), 2010, 89-95.

[12] FAO, Amino acid contents of foods and biological data on protein, Food policy and food science service, $1970,72$.

[13] FAO, Food composition table for the near East nuts and seeds, FAO food and nutrition paper, 26, $1982,85$.

[14] A.O. Ojokoh, R.T. Lawal, Changes in nutrient content of popcorn and groundnut composite flours subjected to solid substrate fermentation, Int. J. Tropical Med. \& Pub. Health, Vol. 1 Issue 1, 50-53.

[15] J.M. Nzikou, L. Mate, G. Bouanga-kalou, C.B. Ndangui, N.P.G. Pambou-Tobi, A. Kimbonguila, T. Silo, M. Linder, S. Desobry, Chemical composition of the seeds and oil of sesame (Sesamun indicum L.) grown in Congo-Brazzaville. Advance Journal of food Science and Technology, 1(1), 2009, 6-11.

[16] M. Murkovic, A. Hillebrand, J. Leither, W. Pfannhanster, Variability of fatty acid content in pumpkin seeds. (Cucurbita pepo L), Zeistchriff-fuer-lebensmittel-untersuchung-und-forschung, 203(3), 1996, 216-219.

[17] G.A. Adebisi, E.O. Olagunju, Nutritional potential of the seed of fluted pumpkin (Telfairia occidentalis), Journal of New Trends in Science and Technology Application, Vol. 1 No 1, 2011, 7-18.

[18] M.N. Ige, A.O. Ogunsua, O.L. Okon, Functional properties of the proteins of some Nigerian oilseeds; Casophor seed and three varieties of some Nigerian oil seeds. Food Chem. 32, 1984, 822-825.

[19] M.J.Y. Lin, E.S. Humbert, F.W. Sosuki, Certain functional properties of sunflower meal products. J. Food Science, 39, 1974, 368370 .

[20] P.I. Akubor, G.I.O. Badifu, Chemical composition, functional properties and baking potential of African breadfruit kernel and wheat flour blends. Int. J. Food Sci. Tech., 39, 2004, 223-229.

[21] M.O. Aremu, A. Olonisakin, D.A. Bako, P.C. Madu, Compositional and physicochemical characteristics of cashewnut (Anacardium occidentale) flour. Pak. J. Nutr. 5(4), 2006, 328-333.

[22] A.A. Taiwo, M.O. Agbotoba, A. Oyedepo, O.A Shobo, I. Oluwadare, M.O Olawuni, Effects of drying methods on properties of watermelon (Citrullus lanatus) seed oil, AJFAND, Vol. 8 No 4, 2008, 492-501.

[23] A.O. Magdi, Chemical and nutrient analysis of Baobab (Adansonia digitata) fruit and seed protein solubility. Plant Foods for Human Nutrition, 59, 2004, 29-33.

[24] F.O. Jimoh, A.T. Oladiji, Preliminary studies on Piliostigma thonningii seeds; proximate analysis, mineral composition and phytochemical screening. African Journal of Biotechnology, Vol.4(12), 2005, 1439-1442.

[25] M.O. Oladimeji, A.O. Adebayo, A.H. Adegbesan, Physicochemical properties of Hausa melon seed flour, Ultra Sci., 13, 2001, 374377. 